\title{
Full employment abandoned: shifting sands and policy failures
}

Citation for published version (APA):

Muysken, J., \& Mitchell, W. F. (2009). Full employment abandoned: shifting sands and policy failures. METEOR, Maastricht University School of Business and Economics. METEOR Research Memorandum No. 006 https://doi.org/10.26481/umamet.2009006

Document status and date:

Published: 01/01/2009

DOI:

10.26481/umamet.2009006

Document Version:

Publisher's PDF, also known as Version of record

\section{Please check the document version of this publication:}

- A submitted manuscript is the version of the article upon submission and before peer-review. There can be important differences between the submitted version and the official published version of record.

People interested in the research are advised to contact the author for the final version of the publication, or visit the DOI to the publisher's website.

- The final author version and the galley proof are versions of the publication after peer review.

- The final published version features the final layout of the paper including the volume, issue and page numbers.

Link to publication

\footnotetext{
General rights rights.

- You may freely distribute the URL identifying the publication in the public portal. please follow below link for the End User Agreement:

www.umlib.nl/taverne-license

Take down policy

If you believe that this document breaches copyright please contact us at:

repository@maastrichtuniversity.nl

providing details and we will investigate your claim.
}

Copyright and moral rights for the publications made accessible in the public portal are retained by the authors and/or other copyright owners and it is a condition of accessing publications that users recognise and abide by the legal requirements associated with these

- Users may download and print one copy of any publication from the public portal for the purpose of private study or research.

- You may not further distribute the material or use it for any profit-making activity or commercial gain

If the publication is distributed under the terms of Article $25 \mathrm{fa}$ of the Dutch Copyright Act, indicated by the "Taverne" license above, 


\section{Maastricht University}

William Mitchell, J oan Muysken

Full employment abandoned: shifting sands and policy failures

RM/09/006

\section{METEOR}

Faculty of Economics and Business Administration Maastricht Research School of Economics

of Technology and Organization

P.O. Box 616

NL - 6200 MD Maastricht

The Netherlands 
Full employment abandoned: shifting sands and policy failures

William Mitchell and Joan Muysken ${ }^{1}$

Revised: January 2009 


\section{Introduction}

In the Post World War 2 period up until the mid-1970s, everybody who wanted to earn an income was able to find employment. Maintaining full employment was an overriding goal of economic policy which governments of all political persuasions took seriously. Unemployment rates below two per cent were considered normal and when unemployment threatened to increase, government intervened by stimulating aggregate demand. Even conservative governments acted in this way, if only because they feared the electoral backlash that was associated with unemployment in excess of 2 per cent.

More fundamentally, employment is a basic human right and this principle was enshrined in the immediate Post World War II period by the United Nations. In 1945, the Charter of the United Nations was signed and ratified by 50 member nations. Article 55 defines full employment as a necessary condition for stability and wellbeing among people, while Article 56 requires that all members commit themselves to using their policy powers to ensure that full employment, among other socioeconomic goals are achieved.

Employment transcends its income generating role to become a fundamental human need and right. This intent was reinforced by the United Nations in the unanimous adoption of the 1948 Universal Declaration of Human Rights. Article 23 of that treaty outlines, among other things, the essential link between full employment and the maintenance of human rights.

(1) Everyone has the right to work, to free choice of employment, to just and favourable conditions of work and to protection against unemployment.

(2) Everyone, without discrimination, has the right to equal pay for equal work.

(3) Everyone who works has the right to just and favourable remuneration, ensuring for himself and his family an existence worthy of human dignity and supplemented, if necessary, by other means of social protection.

(4) Everyone has the right to form and to join trade unions for the protection of his interests.

While unemployment was seen as a waste of resources and a loss of national income which together restrained the growth of living standards, it was also constructed in terms of social and philosophical objectives pertaining to dignity, well-being and the quest for sophistication. It was also clearly understood that the maintenance of full employment was the collective responsibility of society, expressed through the macroeconomic policy settings. Governments had to ensure that there were jobs available that were accessible to the most disadvantaged workers in the economy. Mitchell and Muysken (2008) call this collective enterprise the Full Employment framework.

This framework has been systematically abandoned in most OECD countries over the last 30 years. The overriding priority of macroeconomic policy has shifted towards keeping inflation low and suppressing the stabilisation functions of fiscal policy. Concerted political campaigns by neo-liberal governments aided and abetted by a capitalist class intent on regaining total control of workplaces, have hectored communities into accepting that mass unemployment and rising underemployment is no longer the responsibility of government. As a consequence, the insights gained from the writings of Keynes, Marx and Kalecki into how deficient demand in 
macroeconomic systems constrains employment opportunities and forces some individuals into involuntary unemployment have been discarded.

The concept of systemic failure has been replaced by sheeting the responsibility for economic outcomes onto the individual. Accordingly, anyone who is unemployed has chosen to be in that state either because they didn't invest in appropriate skills; haven't searched for available opportunities with sufficient effort or rigour; or have become either "work shy" or too selective in the jobs they would accept. Governments are seen to have bolstered this individual lethargy through providing excessively generous income support payments and restrictive hiring and firing regulations.

The prevailing view held by economists and policy makers is that individuals should be willing to adapt to changing circumstances and individuals should not be prevented in doing so by outdated regulations and institutions. The role of government is then prescribed as one of ensuring individuals reach states where they are employable. This involves reducing the ease of access to income support payments via pernicious work tests and compliance programs; reducing or eliminating other "barriers" to employment (for example, unfair dismissal regulations); and forcing unemployed individuals into a relentless succession of training programs designed to address deficiencies in skills and character. Mitchell and Muysken (2008) call this new paradigm the Full Employability framework.

The framework is exemplified in the 1994 Jobs Study published by the Organisation of Economic Cooperation and Development (OECD). Its main message (OECD, 1994, vii) accurately summarises the current state-of-the-art in policy thinking

... it is an inability of OECD economies and societies to adapt rapidly and innovatively to a world of rapid structural change that is the principal cause of high and persistent unemployment. ... Consequently, the main thrust of the study was directed towards identifying the institutions, rules and regulations, and practices and policies which have weakened the capacity of OECD countries to adapt and to innovate, and to search for appropriate policy responses in all these areas. ...

Action is required in all areas simultaneously for several reasons. First, the roots of structural unemployment have penetrated many if not all areas of the socioeconomic fabric; second, the political difficulties of implementing several of these policies call for a comprehensive strategy ... third, there are synergies to exploit if various microeconomic polices are pursued in a co-ordinated way, both with regard to each other and the macroeconomic policy stance.

The OECD Jobs Study (1994: 74) also ratified the growing macroeconomic conservatism by articulating that the major task for macroeconomic policy was to allow governments to 'work towards creating a healthy, stable and predictable environment allowing sustained growth of investment, output and employment. This implies a reduction in structural budget deficits and public sector debt over the medium term ... [together with] ... low inflation.'

The OECD has claimed that its policy recommendations have delivered successes in countries that have implemented them (see OECD, 2001). Unfortunately, the reality is strikingly at odds with this political hubris. Some 13 years have passed since the OECD policy agenda was declared and yet most countries are still languishing in high states of labour underutilisation and low to moderate economic growth. 
Underemployment is becoming an increasingly significant source of wastage. Youth unemployment remains high. Income inequalities are increasing.

The only achievement is that inflation was brought under control, although it was the severity of the 1991 recession that expunged inflationary expectations from the OECD block. Since that time, labour costs have been kept down by harsh industrial relations deregulation and a concerted attack on the labour unions. The policy approach used to banish one of the twin evils - inflation - has left the evils of unemployment and underemployment in its wake. Even this "stability" is now being threatened by the power of the OPEC cartel who is acting in the similar way to when it drove oil prices up in the 1970s and pushed the World economy into stagflation.

At present, after 30 years of public expenditure cutbacks and, more recently, increasing government bullying of the jobless, OECD economies generally are not close to achieving full employment. In the midst of the on-going debates about labour market deregulation, scrapping minimum wages, and the necessity of reforms to the taxation and welfare systems, the most salient, empirically robust fact of the last three decades - that actual GDP growth has rarely reached the rate required to maintain, let alone achieve, full employment - has been ignored (Mitchell, 2001a).

The emergence of a social underclass has accompanied the long period of labour market slack. Unemployment is the primary driver of social exclusion and the jobless quickly experience a broad set of disadvantages that go well beyond the loss of income.

Most of the blame for this labour underutilisation across OECD countries lies with the policy failures of national governments. At a time when budget deficits should have been used to stimulate the demand needed to generate jobs for all those wanting work, various restrictions have been placed on fiscal policy by governments influenced by orthodox macroeconomic theory. Monetary policy has also become restrictive, with inflation targeting - either directly or indirectly - pursued by increasingly independent and vigilant central banks. These misguided fiscal and monetary stances have damaged the capacities of the various economies to produce enough jobs.

The attacks on the welfare system have, in part, been driven by the overall distaste among the orthodox economists for the activist fiscal policy essential to the maintenance of full employment. Counter-cyclical fiscal policy is now eschewed and monetary policy has become exclusively focused on inflation control. There are many arguments (fears) used to justify this position, including the (alleged) dangers of inflation and the need to avoid crowding out in financial markets.

We argue that governments who have chosen to adopt what we call the full employability policy paradigm and hence have allowed their economies to wallow in high states of labour underutilisation have violated the 1948 Universal Declaration of Human Rights, which is underpinned by international law. In that sense they are violating the human rights of their unemployed and underemployed citizens.

This changed perception on the nature and importance of unemployment has not been a fruitful path for society to follow especially when a full employment alternative exists, which is grounded in the principles of modern monetary economics (see Mitchell and Muysken, 2008 for more detail).

This paper briefly analyses the shifts in economic theory that have moved us from authorising policy makers to unambiguously pursue full employment, to the current state where full employability is justified as being optimal. We argue that the rise of 
Monetarism and the concept of the natural rate of unemployment did not represent a continuous refinement of the macroeconomic orthodoxy of the time but were simply a reassertion of the Classical belief in the efficacy of the free market and the denial that generalised overproduction could occur in a capitalist economy. The resurgence of these notions in the 1970s overran the Keynesian orthodoxy and authorised policy makers to abandon full employment as an integral macroeconomic policy goal.

We explore how these theoretical developments translated in practice, culminating in the broad acceptance by policy makers of the full employability framework. We focus on the policy emphasis accorded to the supply-side, exemplified in the 1994 OECD Jobs Study which eschewed a role for macroeconomic policy in reducing unemployment. It is important to document how structural explanations for unemployment have been used to justify widespread labour market deregulation; attacks on the rights and capacities of labour unions to represent their members; wasteful privatisations of public assets; the compliance focus of welfare-to-work policy, a retrenchment of the role of the public sector as an employer, and widespread reductions in the social wage. We also consider the way in which macroeconomic policy, characterised by inflation targeting and a growing fiscal conservatism, has supported this microeconomic emphasis on structural reform. While the current orthodoxy extols the virtues of budget surpluses as the exemplars of fiscal responsibility, we show in later sections that this policy stance is, in fact, damaging for economic growth.

The paper concludes that these policy changes have not achieved the targets espoused in the political statements and have instead created a growing underclass of unemployed, underemployed and disadvantaged citizens.

The final section of the paper outlines an alternative view of macroeconomic theory and policy opportunities. This view flows from a detailed understanding of modern monetary systems in which the use of fiat currency provides the monopoly issuer, the federal government, with opportunities to pursue full employment without compromising price stability. We show that the obsession held by federal governments around the world that budget surpluses demonstrate fiscal prudence is both nonsensical and extremely costly. Once we understand how the surpluses relate to sectoral flows in the economy, it follows that active macroeconomic policy is essential to maintaining full employment. We argue that a central plank in modern macroeconomic policy settings should be the introduction of employment guarantees, which we term the Job Guarantee (JG). We show that the introduction of a JG provides the basis for pursuing full employment and price stability. The JG is also the minimum that a government can do in relation to its obligations under the international human rights treaties discussed earlier.

\section{Full employment, citizenship and safety net redistribution}

Figure 1 sketches the Full Employment framework (Mitchell and Muysken, 2008). The Post World War 2 economic and social settlement in most Western countries was based on three main pillars. First, the Economic Pillar was defined by an unambiguous commitment to full employment, although this commitment became blurred in the debate about the trade-off between inflation and unemployment in the 1960s. Second, the Redistributive Pillar was designed to ameliorate market outcomes and defined much of the equity intervention by government. It recognised that the free market was amoral and intervention in the form of income support and wage setting 
norms was a necessary part of a sophisticated society. Third, the Collective Pillar provided the philosophical underpinning for the Full Employment framework and was based on the intrinsic rights of citizenship. We accept that our depiction is a stylisation and that there were many individual nuances in particular countries over the period considered.

Figure 1 The Pillars of the Full Employment framework

The Full Employment framework

\begin{tabular}{|c|c|c|}
\hline $\begin{array}{c}\text { Economic Pillar } \\
\text { Commitment to Full } \\
\text { Employment }\end{array}$ & $\begin{array}{c}\text { Redistributive Pillar } \\
\text { Intervention to } \\
\text { ameliorate market } \\
\text { outcomes }\end{array}$ & $\begin{array}{c}\text { Collective Pillar } \\
\text { Rights of citizenship }\end{array}$ \\
\hline$\downarrow$ & $\downarrow$ & $\downarrow$ \\
\hline $\begin{array}{l}\text { Keynesian fiscal and } \\
\text { monetary demand } \\
\text { management }\end{array}$ & $\begin{array}{l}\text { Transfer payments } \\
\text { Redistributive } \\
\text { taxation }\end{array}$ & $\begin{array}{l}\text { Uniform services } \\
\text { Pursuit of collective } \\
\text { will }\end{array}$ \\
\hline $\begin{array}{ll}\text { Public } & \text { sector } \\
\text { employment } & \end{array}$ & $\begin{array}{l}\text { Services to enable } \\
\text { participation }\end{array}$ & $\begin{array}{l}\text { Professional } \\
\text { administration }\end{array}$ \\
\hline $\begin{array}{l}\text { Employer of Last } \\
\text { Resort }\end{array}$ & Regulation & $\begin{array}{l}\text { Services delivered } \\
\text { by the state }\end{array}$ \\
\hline $\begin{array}{l}\text { Government } \\
\text { mediates the class } \\
\text { struggle }\end{array}$ & $\begin{array}{lr}\text { Conciliation } & \text { and } \\
\text { Arbitration via } & \text { vialist tribunals } \\
\text { speciali }\end{array}$ & $\begin{array}{l}\text { Rights embodied in } \\
\text { legislation }\end{array}$ \\
\hline
\end{tabular}

Source: Mitchell and Muysken (2008: Figure 1.1).

The Great Depression taught us that, without government intervention, capitalist economies are prone to lengthy periods of unemployment. The emphasis of macroeconomic policy in the period immediately following the Second World War was to promote full employment. Inflation control was not considered a major issue even though it was one of the stated policy targets of most governments. In this period, the memories of the Great Depression still exerted an influence on the constituencies that elected the politicians. The experience of the Second World War showed governments that full employment could be maintained with appropriate use of budget deficits. The employment growth following the Great Depression was in direct response to the spending needs that accompanied the onset of the War rather than the failed neoclassical remedies that had been tried during the 1930s. The problem that had to be addressed by governments at War's end was to find a way to translate the fully employed War economy with extensive civil controls and loss of liberty into a fully employed peacetime model. 
The first major statement addressing this problem came in the form of William Beveridge's (1944) Full Employment in a Free Society. This was consistent with the emerging Keynesian orthodoxy of the time, which saw unemployment as a systemic failure in demand and moved the focus away from an emphasis on the ascriptive characteristics of the unemployed and the prevailing wage levels. Beveridge (1944, 123-135) said 'The ultimate responsibility for seeing that outlay as a whole ... is sufficient to set up a demand for all the labour seeking employment, must be taken by the State.'

The emphasis was on jobs. Beveridge defined full employment as an excess of vacancies at living wages over unemployed persons. Creating enough jobs in the economy was seen as the best form of social security. Arthur Altmeyer (1968) ${ }^{2}$ in one of his last speeches talked about the adoption of Beveridge's Report on Social Security by Churchill, who Altmeyer said, 'was on the side of social security and opposed to the alms house which had been tried for several hundred years and had failed.'

From 1945 until 1975, governments manipulated fiscal and monetary policy to maintain levels of overall spending sufficient to generate employment growth in line with labour force growth. This was consistent with the view that mass unemployment reflected deficient aggregate demand which could be resolved through positive net government spending (budget deficits). Governments used a range of fiscal and monetary measures to stabilise the economy in the face of fluctuations in private sector spending and were typically in deficit.

As a consequence, in the period between 1945 through to the mid 1970s, most advanced Western nations maintained very low levels of unemployment, typically below 2 per cent. Figure 2 shows that the performance of the labour market during the Keynesian full employment period was in stark contrast to what followed and what had preceded it.

Figure 2 Unemployment rates, Australia, Europe and the United States, 1950 to 2006

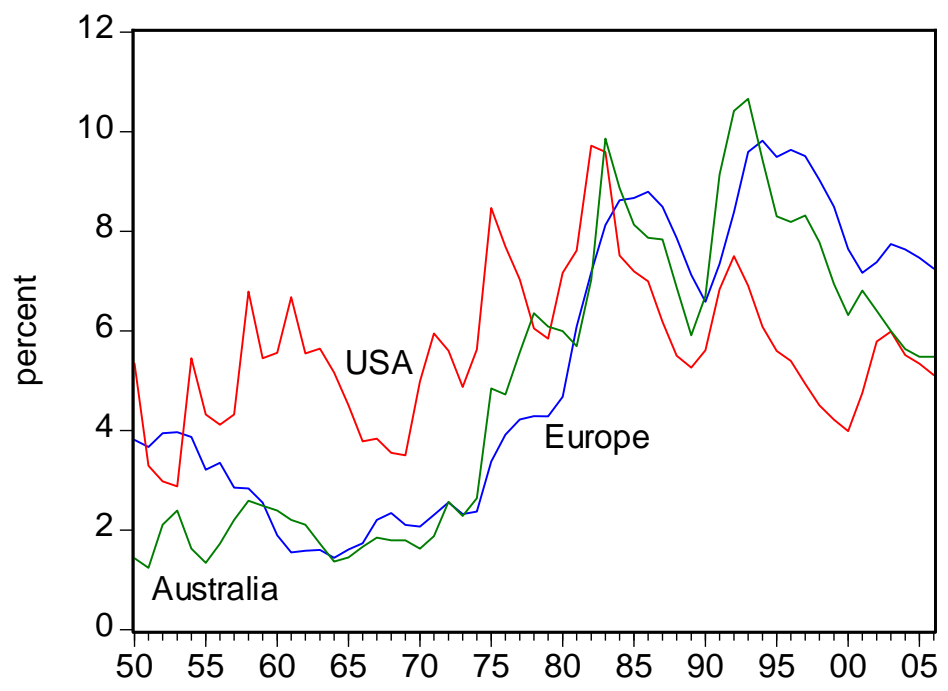

Source: Mitchell and Muysken (2008: Figure 1.2).

However, while both private and public employment growth was relatively strong during the Post War period up until the mid 1970s, the major reason that the economy was able to sustain full employment was that it maintained a buffer of jobs that were 
always available, and which provided easy employment access to the least skilled workers in the labour force. Some of these jobs, such as process work in factories, were available in the private sector. However, the public sector also offered many buffer jobs that sustained workers with a range of skills through hard times. In some cases, these jobs provided permanent work for the low skilled and otherwise disadvantaged workers.

Importantly, the economies that avoided the plunge into high unemployment in the 1970s maintained what Ormerod (1994: 203) has described as a '...sector of the economy which effectively functions as an employer of last resort, which absorbs the shocks which occur from time to time, and more generally makes employment available to the less skilled, the less qualified.' Ormerod said that employment of this type may not satisfy narrow neoclassical efficiency benchmarks, but notes that societies with a high degree of social cohesion and a high valuation on collective will have been willing to broaden their concept of costs and benefits of resource usage to ensure everyone has access to paid employment opportunities.

Ormerod (1994: 203) argued that countries like Japan, Austria, Norway, and Switzerland were able to maintain this capacity because each exhibited '....a high degree of shared social values, of what may be termed social cohesion, a characteristic of almost all societies in which unemployment has remained low for long periods of time.' In Sections 5 and 6 we summarise the argument that in a modern monetary economy the return to full employment and price stability requires the reintroduction of this buffer stock capacity (Mitchell, 1998; Mitchell and Mosler, 2006).

The full employment commitment (the Economic Pillar) was buttressed by the development of the Welfare State, which defined the state's obligation to provide security to all citizens. Citizenship embraced the notion that society had 'a collective responsibility for the wellbeing of its citizens' (Jamrozik, 2001: 15) and replaced the dichotomy that had been constructed between the deserving and undeserving poor (Timmins, 1995: 21). The Redistributive Pillar recognised that the mixed economy (with a large market-component) would deliver poor outcomes to some citizen, principally via unemployment. Extensive transfer payments programs were designed to provide income support to disadvantaged individuals and groups. Underpinning the Welfare State and the economic commitment to full employment was a sophisticated concept of citizenship (the Collective Pillar). The rights of citizenship meant that individuals had access to the distribution system (via transfer payments) independent of market outcomes. Furthermore, a professional public sector provided standardised services at an equivalent level to all citizens as a right of citizenship. These included the public sector employment services, public health and education systems, legal aid and a range of other services.

\section{The abandonment of full employment}

The stability of this Post-War framework with the Government maintaining continuous full employment via policy interventions was always a source of dissatisfaction for the capitalist class. This was particularly the case in the late 1960s as national debates arose about trade union power (see Quirk, 2003). Taking Australia as an example, Quirk (2003) provides compelling evidence to show that the captains of industry were pressuring government to create some labour slack in the economy and that the entreaties were received sympathetically by key conservative politicians. However, the chance to break the Post-War stability came in the mid-1970s. 
Following the first OPEC oil price hike in 1974, which led to accelerating inflation in most countries, there was a resurgence of pre-Keynesian thinking. Inflationary impulses associated with the Vietnam War had earlier provided neo-liberal economists with opportunities to attack activist macroeconomic policy in the United States. Governments around the world reacted with contractionary policies to quell inflation and unemployment rose giving birth to the era of stagflation. The economic dislocation that followed provoked a paradigm shift in macroeconomics (Thurow, 1983).

The Keynesian notion of full employment, defined by Vickrey (1993) as 'a situation where there are at least as many job openings as there are persons seeking employment' was abandoned as policy makers progressively adopted the natural rate of unemployment approach (Friedman, 1968). This has more recently been termed the Non-Accelerating Inflation Rate of Unemployment (NAIRU) approach (see Mitchell and Muysken, 2008 for a full account of this transition). This approach redefines full employment in terms of a unique unemployment rate (the NAIRU) where inflation is stable, and which is determined by supply forces and is invariant to Keynesian demand-side policies. It reintroduces the discredited Say's Law by alleging that free markets guarantee full employment and Keynesian attempts to drive unemployment below the NAIRU will ultimately be self-defeating and inflationary. The Keynesian notion that unemployment represents a macroeconomic failure that can be addressed by expansionary fiscal and/or monetary policy is rejected. Instead, unemployment reflects failures on the supply side failures such as individual disincentive effects arising from welfare provision, skill mismatches, and excessive government regulations (OECD, 1994). Extreme versions of the natural rate hypothesis consider unemployment to be voluntary and the outcome of optimising choices by individuals between work (bad) and leisure (good).

As, what is now referred to as, neo-liberalism took hold in the policy making domains of government, advocacy for the use of discretionary fiscal and monetary policy to stabilise the economy diminished. In the mid-1970s the opposition to the use of budget deficits to maintain full employment became visible for the first time and the inflation-first rhetoric emerged as the dominant discourse in macroeconomic policy debates. $^{3}$ The rhetoric was not new and had previously driven the failed policy initiatives during the Great Depression. However, history is conveniently forgotten and Friedman's natural rate hypothesis seemed to provide economists with an explanation for high inflation and alleged three main and highly visible culprits - the use of government deficits to stimulate the economy; the widespread income support mechanisms operating under the guise of the Welfare State; and the excessive power of the trade unions which had supposedly been nurtured by the years of full employment. All were considered to be linked and anathema to the conditions that would deliver optimal outcomes as prescribed in the neoclassical economic (textbook) model. Mitchell and Muysken (2008) provide a full account of the technical aspects of these issues.

With support from business and an uncritical media, the paradigm shift in the academy permeated the policy circles and as a consequence governments relinquished the first major pillar of the Post-War framework - the commitment to full employment. It was during this era that unemployment accelerated and has never returned to the low levels that were the hallmark of the Keynesian period. 
The NAIRU approach extolled, as a matter of religious faith, that government could only achieve better outcomes (higher productivity, lower unemployment) through microeconomic reforms. In accordance with the so-called supply-side economics, governments began to redefine the Economic Pillar in terms of creating a greater reliance on market-based economic outcomes with a diminished public sector involvement. In many countries successive governments began cutting expenditures on public sector employment and social programs; culled the public capacity to offer apprenticeships and training programs, and set about dismantling what they claimed to be supply impediments (such as labour regulations, minimum wages, social security payments and the like).

Within this logic, governments adopted the goal of full employability, significantly diminishing their responsibility for the optimum use of the nation's labour resources. Accordingly, the aim of labour market policy was limited to ensuring that individuals are employable. This new ambition became exemplified in the 1994 OECD Jobs Study.

As a result, successive governments in many countries began the relentless imposition of active labour market programs. These were designed to churn the unemployed through training programs and/or force participation in workfare compliance programs. The absurdity of requiring people to relentlessly search for work, and to engage in on-going training divorced of a paid-work context, seemed lost on government and their policy advisors. That the NAIRU approach seduced them at all is more difficult to understand given stark evidence that since 1975 there have never been enough jobs available to match the willing labour supply.

In the UK Richard Layard (1998: 27), an influential Labor Party advisor, noted

In the very bad old days, people thought unemployment could be permanently reduced by stimulating aggregate demand in the economy ... But ... [this] ...did not address the fundamental problem; to ensure that inflationary pressures do not develop while there are still massive pockets of unemployed people. The only way to address this problem is to make all the unemployed more attractive to employers - through help with motivation and job finding, through skillformation, and through a flexible system of wage differentials. Nothing else will do the trick.

The OECD Jobs Study (1994), which was considerably influenced by the work of Layard and his colleagues, set the tone for this neo-liberal labour market agenda. Mitchell and Muysken (2008) show that this agenda makes the goal of full employability pre-eminent and disregards policies that might increase the rate of overall job creation.

A fully employed economy provides life-long training and learning opportunities in the context of paid employment. Firms become responsible for adjusting hiring standards and on-the-job training programs to match the available talents of the labour force. Under the flawed doctrine of full employability, labour market programs mainly function to subsidise the needs of private capital. Further, unemployment has become a business. Many market-based organisations have benefited from this new approach to delivering labour market services. Small entrepreneurs, community activists, and private welfare agencies have become the agencies that administer these neo-liberal labour market policies (Peck, 2001). 
In the UK, Jones and MacLeod (2002: 20) noted

... employer coalitions and locally based stakeholder partnerships have been formed to bring together a wide range of interests involved in the "business" of unemployment. Through these new regimes, the unemployed are offered to employers, who receive a subsidy with minimum training requirements, in return for their assistance in resolving welfare state dependency and at the same time (supposedly) providing the basis for a skills-based lifelong learning revolution ... While this might give some genuine appearance of "training", some have gone so far as to suggest this is nothing more than large-scale bribery, a huge subsidy for capital, because the training requirements are ill-defined in the numerous agreements between the employer and the state.

The shift to an emphasis on full employability was accompanied by substantial changes in the conduct of macroeconomic policy. Mitchell and Muysken (2008) show that inflation targeting, which was one strand of the macroeconomic accompaniment to the supply side microeconomic policy agenda set out in the 1994 Jobs Study, weakened the ability of macroeconomic policy to counter cyclical fluctuations. Not only have the neo-liberals rejected the notion that demand deficiencies can occur, but they have also been successful in making inflation appear to be a worse bogey person than unemployment. Blinder (1987: 51) presented a compelling critique of this view and concludes that the political importance of inflation has been blown out of all proportion to its economic significance. After dismissing the arguments that inflation imposes high costs on the economy, Blinder (1987: 33) noted ${ }^{4}$

The political revival of free-market ideology in the 1980s is, I presume, based on the market's remarkable ability to root out inefficiency. But not all inefficiencies are created equal. In particular, high unemployment represents a waste of resources so colossal that no one truly interested in efficiency can be complacent about it. It is both ironic and tragic that, in searching out ways to improve economic efficiency, we seem to have ignored the biggest inefficiency of them all.

Solow (1998), reflecting his Keynesian roots, is also critical of the emphasis on inflation. He argued that inflationary pressures do not emanate from low-wage labour markets. Solow (1998: 32-33) is sceptical that labour markets drive inflation at all and said that 'it seems wholly unlikely that unskilled wage-push plays much of an independent inflationary role ... [so] ... an influx of former recipients will not give the Federal Reserve much of a cushion against over-heating.' Mitchell and Muysken (2008) provided a detailed account of these issues.

\section{The Full Employability framework and the abandonment of the rights of citizenship}

The abandonment of full employment presented neo-liberal governments with a new problem. With unemployment persisting at high levels due to the deliberate constraints imposed on the economy by restrictive fiscal (and monetary) policy, rising welfare payments placed pressures on the Redistributive Pillar. These pressures were erroneously seen as a threat to the fiscal position of government. As we explain in Section 5, Government is never financially constrained and the justification for cutting welfare to 'save money' is flawed at the most elemental level.

However, the neo-liberals managed to convince policy makers that fiscal conservatism was necessary and that the only way to resolve the pressures on the Redistributive Pillar was to reduce the public commitment to income support and the 
pursuit of equity. Accompanying the neo-liberal attacks on macroeconomic policy were concerted attacks on the supplementary institutions such as the industrial relations system and the Welfare State. For these attacks to be effective required a major recasting of the concept of citizenship. Governments, aided by the urgings of the neo-liberal intellectuals in the media and in conservative think tanks, thus set about redefining the Collective Pillar, which had been an essential part of the rationale for the system of social security.

Figure 1.3 The Full Employability framework

The Full Employability framework

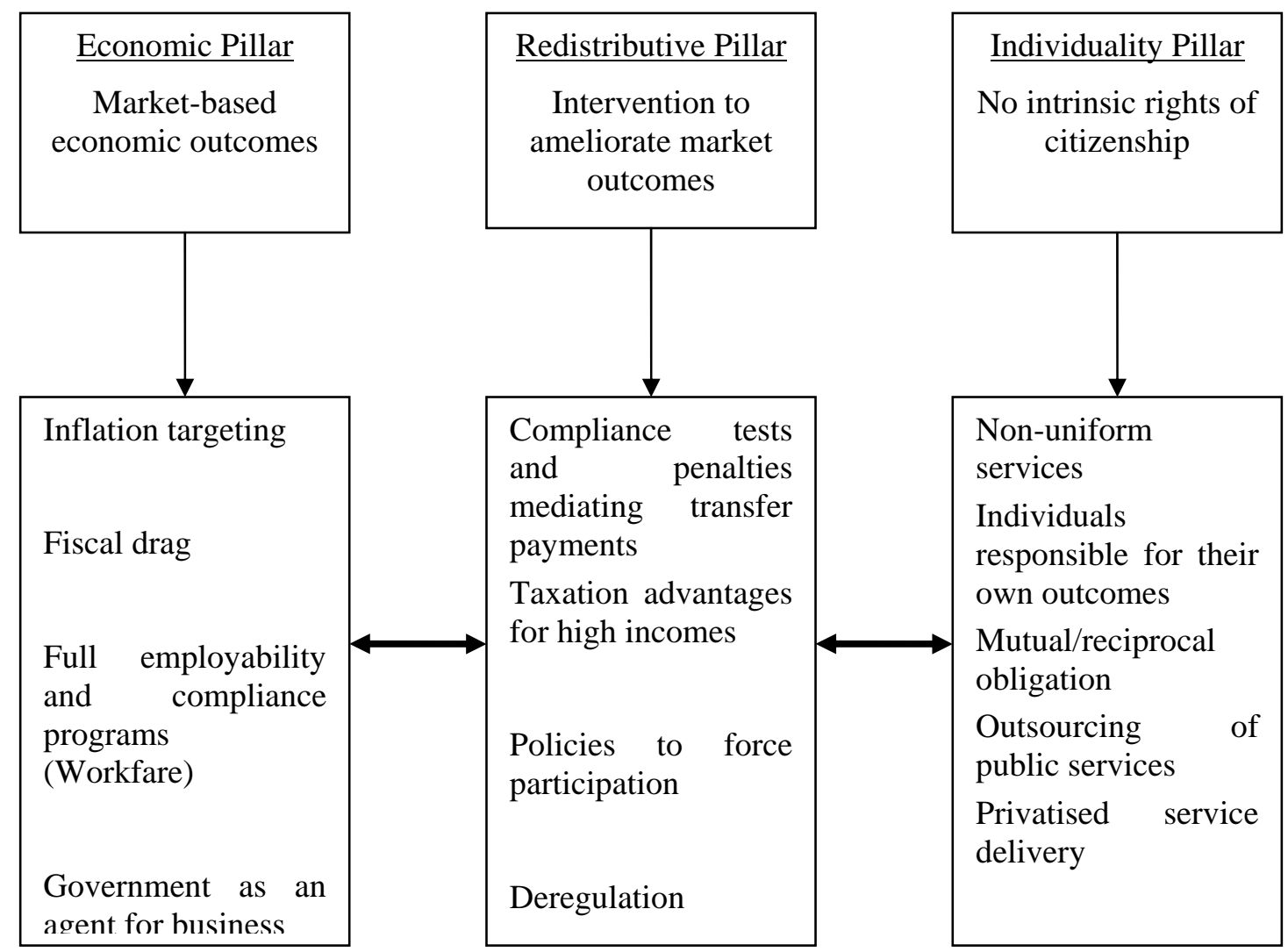

Source: Mitchell and Muysken (2008: Figure 1.3).

Under the Full Employability framework, which we sketch in Figure 3, collective will has been usurped by the primacy of the individual. The hallmark of the neo-liberal era is that individuals have to accept responsibility, be self-reliant, and fulfill their obligations to society (Giddens, 1998). Unemployment is couched as a problem of welfare dependence rather than a deficiency of jobs.

To break this welfare dependency required responsibility to be shifted from government to the individual. To force individuals to become accountable for their own outcomes, governments embraced a shift from active to passive welfare and the introduction of alleged responsibilities to counter-balance existing rights. This is sometimes referred to as reciprocal obligation (Cook et al., 2003). Individuals now 
face broader obligations and, in many countries, their rights as citizens have been replaced by compulsory contractual relationships under which receipt of benefits is contingent on meeting behavioural criteria. Reciprocal obligation was developed as a leading principle in several countries as a means of reintegrating the allegedly, welfare dependent underclass into the community.

Unfortunately, there is no reciprocal obligation on government to ensure that there are enough jobs for all those wanting work. The major shortcoming of the Full Employability framework is that the focus on the individual ignores the role that macroeconomic constraints play in creating welfare dependence. It is a compositional fallacy to consider that the difference between getting a job and being unemployed is a matter of individual endeavour or preference. Adopting welfare dependency as a lifestyle is different to an individual, who is powerless in the face of macroeconomic failure, seeking income support as a right of citizenry.

\section{A modern monetary economics: macroeconomic principles revisited}

In this Section we summarise the arguments developed by Mitchell and Muysken (2008) which centre on what we term modern monetary theory. We use this term to define a monetary system characterised by a floating exchange rate (so monetary policy is freed from the need to defend foreign exchange reserves) and the monopoly provision of fiat currency. The monopolist is the national government. The consolidated government sector comprises the central bank and treasury. Their various operations - spending and taxing (treasury); open market operations, currency transactions etc (central bank) provide net injections (positive or negative) of fiatcurrency to the non-government sector. Most countries now operate monetary systems that have these characteristics. ${ }^{5}$ The following macroeconomic principles explain the fundamental flaws in the arguments used to justify abandoning full employment in the context of a modern monetary economy.

First, under a fiat currency system, the monetary unit defined by the government has no intrinsic worth. It cannot be legally converted by government, for example, into gold as it was under the gold standard. The viability of the fiat currency is ensured by the fact that it is the only unit which is acceptable for payment of taxes and other financial demands of the government.

Second, the analogy neo-liberals draw between private household budgets and the government budget is false. Households, the users of the currency, must finance their spending prior to the fact. However, government, as the issuer of the currency, must spend first (credit private bank accounts) before it can subsequently tax (debit private accounts). Government spending is the source of the funds the private sector requires to pay its taxes and to net save. Moreover, since government controls the provision of the fiat currency, it is not inherently revenue constrained.

Third, unemployment occurs when net government spending is too low. As a matter of accounting, for aggregate output to be sold, total spending must equal total income (whether actual income generated in production is fully spent or not each period). Involuntary unemployment is idle labour unable to find a buyer at the current money wage. In the absence of government spending, unemployment arises when the private sector, in aggregate, desires to spend less of the monetary unit of account than it earns. Nominal (or real) wage cuts per se do not clear the labour market, unless they somehow eliminate the private sector desire to net save and increase spending. Thus, 
unemployment occurs when net government spending is too low to accommodate the need to pay taxes and the desire to net save.

Fourth, as a matter of national accounting, the federal government deficit (surplus) equals the non-government surplus (deficit). The failure to recognise this relationship is the major oversight of neo-liberal analysis. In aggregate, there can be no net savings of financial assets of the non-government sector without cumulative government deficit spending. The federal government via net spending (deficits) is the only entity that can provide the non-government sector with net financial assets (net savings) and thereby simultaneously accommodate any net desire to save and hence eliminate unemployment. Additionally, and contrary to neo-liberal rhetoric, the systematic pursuit of government budget surpluses is necessarily manifested as systematic declines in private sector savings.

Fifth, the decreasing levels of net private savings financing the government surplus increasingly leverage the private sector. The deteriorating debt to income ratios which result will eventually see the system succumb to ongoing demand-draining fiscal drag through a slow-down in real activity.

Sixth, while the federal government is not financially constrained it still issues debt to control its liquidity impacts on the private sector. Government spending and purchases of government bonds by the central bank add liquidity, while taxation and sales of government securities drain private liquidity. These transactions influence the cash position of the system on a daily basis and on any one day they can result in a system-wide liquidity surplus (deficit) due to the outflow of funds from the official sector being above (below) the funds inflow to the official sector. The system cash position has crucial implications for the central bank, since the central bank targets the level of short-term interest rates as its monetary policy position. Budget deficits result in system-wide surpluses (excess bank reserves). Competition between the commercial banks to create better earning opportunities on the surplus reserves then puts downward pressure on the cash rate. If the central bank desires to maintain the current target cash rate then it must drain this surplus liquidity by selling government debt. In other words, government debt functions as interest rate support via the maintenance of desired reserve levels in the commercial banking system and not as a source of funds to finance government spending.

\section{Buffer stocks and price stabilisation - the Job Guarantee}

Mitchell and Muysken (2008) compare two different buffer stock approaches to maintaining stable prices. The first, the NAIRU approach, uses unemployment to discipline the wage-price setting process. The second is based on employment buffer stocks and allows the government to achieve both full employment and price stability. The Job Guarantee (JG) proposal, which was conceived independently by Mitchell (1998) and Mosler (1997-98) is an employment buffer stock approach to full employment.

Under the JG, the public sector offers a fixed wage job to anyone willing and able to work. When private sector employment declines, public sector employment will automatically react and increase its payrolls. The JG thus fulfills an absorption function to minimise the real costs currently associated with the flux of the private sector. On the other hand, when private employment expands, wages will rise above the minimum wage and workers will find employment in the private sector. The nation always remains fully employed, with only the mix between private and public 
sector employment fluctuating in response to the spending decisions of the private sector.

Since the JG wage is open to everyone, it will functionally become the national minimum wage. The JG introduces no relative wage effects and the rising demand perse does not necessarily invoke inflationary pressures because by definition it is satisfying a net savings desire.

Additionally, in today's demand constrained economies, firms are likely to increase capacity utilisation to meet the higher sales volumes. There are no new problems faced by employers who wish to hire labour to meet the higher sales levels. Any initial rise in demand will stimulate private sector employment growth while reducing JG employment and spending. Also the JG wage provides an in-built inflation control mechanism: If the private sector is inflating, a tightening of fiscal and/or monetary policy shifts workers into the fixed-wage JG sector to achieve inflation stability without unemployment (Mitchell, 1998, Mosler, 1997-98).

\section{The Job Guarantee, social inclusion and community development}

The JG is not only a valid instrument for macroeconomic stabilisation whereby government can maintain full employment and price stability. In addition, an employment buffer stock approach provides communities with opportunities to revive the social dimension of work, which we emphasised in Sections 1 and 2 above when discussing the Full Employment framework and the concept of employment as a human right.

Amongst others, we argue that the JG would help communities in disadvantaged areas to maintain continuity of income and labour force attachment, without recourse to welfare dependence. In that context the concept of work itself can be extended and broadened to include activities that we would dismiss as being leisure using the current ideology and persuasions. The JG mechanism can also be used to discourage private sector activities currently deemed as productive, in a narrow economic sense, but which future societies will view as socially or environmentally destructive.

Importantly, a JG strategy acknowledges the strains on our natural ecosystems and the need to change the composition of final output towards environmentally sustainable activities. Environmental projects are ideal targets for public sector employment initiatives as they are likely to be under-produced by the private sector due to their heavy public good component. If a portion of JG jobs were used to repair and restore the environment, the workers would re-gain personal dignity, and society would gain from the increased provision of goods and services which support sustainability. It is not increased demand per se that is necessary but increased demand in sustainable areas of activity.

The JG also does not preclude training initiatives. Appropriately structured training within a paid employment context helps overcome the churning of unemployed through training programs, workfare and other schemes under current neo-liberal policies. Specific skills are usually more efficiently taught on the job. As a consequence, a properly designed JG can help previously unemployed persons to make transitions into careers in the private sector and also stimulate employers to modify their recruitment behaviour.

Clearly the JG solves the problem of time-related underemployment. The JG workers can voluntarily choose what fraction of full-time hours they wish to work. As a 
consequence, the introduction of a JG, which provides the opportunity for workers to engage in full time employment, would likely place pressure on private employers, who have failed to provide sufficient hours of work to satisfy the preferences of their workforces, to restructure their workplaces to overcome the discontent that their underemployed workers feel.

The introduction of a JG has no necessary bearing on the availability or operations of existing income support payments. Existing unemployment benefit schemes could easily co-exist with a JG scheme and workers could be given a choice as to whether they accept income support or work in a JG job for a wage. What a JG does is to provide jobs to all who want to work. Most public policy today uses the stick to force those who are able to work off welfare without providing the carrot in the form of jobs. Most welfare-to-work schemes are little more than a cruel joke, precisely because there is no job for most welfare-leavers.

The introduction of a JG is an essential part of a package of policies aimed at restoring full employment and equity with due consideration for price stabilisation. Mitchell and Muysken (2008) consider more fully additional policy initiatives that might be considered by government in this regard.

\section{Conclusion}

We began by noting the fundamental proposition that we consider employment to be an intrinsic human right. The urgency of full employment transcends economic exigencies such as maximisation of income and goes to the basis of how we treat each other. There are various reasons why employment should be considered a human right (see Mitchell and Muysken, 2008). The relevant concepts motivating this claim are citizenship and membership. The Universal Declaration of Human Rights clearly includes the right to work and the 1946 International Labour Office (ILO) Declaration of Philadelphia, ratified by the United Nations, asserts full employment as a national and international goal (Siegel, 1994: 60).

There are three main, interrelated reasons to support the claim that employment is a right. First, for the majority of individuals and households, employment is the dominant source of income. Income is essential for participation in the market economy. It provides access to credit and a diversity of goods and services. It allows a person to save and plan for holidays and retirement. The Full Employment framework clearly acknowledged the need for income support mechanisms for those who were not in receipt of labour income. Redistributive mechanisms in the form of unemployment, age and sickness benefits were based on the primacy of wage income as a means for social inclusion. Second, unemployment and underemployment deprive a person access to social networks and the advantages that they provide. Third, an unemployed person is susceptible to a range of social pathologies including a higher incidence of family breakdown, alcohol and substance abuse, deteriorating physical and mental health, participation in criminal activity and incarceration (Mitchell and Muysken, 2008).

The right to work can be interpreted in many ways. We consider that several dimensions are non-negotiable. A person should be able to obtain the hours of work they desire and this should be guaranteed by the state. This guarantee should provide, at the very least, unconditional offers of work at the minimum adult pay rates and conditions. The guarantee should provide opportunities that are inclusive of the most disadvantaged workers in the economy including people with mental illness or 
disability, should they wish to work. The guaranteed work has to satisfy all legal and moral standards of the day. The JG is a minimalist interpretation of the right to work in that the jobs on offer may still not fully utilise the current skills of those seeking employment. In this regard, the guaranteed employment is seen as a buffer stock to tide people over when they are unable to attain higher paid employment in the (public or private) market sector. We would consider this consistent with the treaties noted above. In this context, a right to work is the precondition for eliminating the enormous costs and consequences of unemployment and requires national governments to take responsibility for maintaining an effective full employment policy.

Most OECD economies have suffered from persistently high unemployment since the mid-1970s. We argue that deficiency of demand promoted by inappropriate fiscal and monetary policy is the major explanation for this problem. We argue that budget deficits are necessary to maintain full employment if the private sector is to pay taxes and has a positive desire to net save. Government spending is only constrained by what real goods and services are offered in return for it and the alleged constraints on government action to restore full employment are based on false premises. In a modern monetary economy, the use of an employment buffer stock approach in the form of a JG is a more effective approach to attaining full employment with price stability than the NAIRU practice of using unemployment as a policy instrument designed to discipline the inflation process. With this underpinning, governments can then begin a process of the restoration of the Full Employment framework and more effectively deal with the challenges of the future, which will come from population ageing and environmental degradation.

\section{References}

Altmeyer, A. (1968) Speech entitled Social Security and the Human Touch given at the $33^{\text {rd }}$ anniversary ceremony of the establishment of Social Security America, August 14, 1968. This was one of his last speeches. From his archives, which are available at the State Historical Society of Wisconsin at Madison, Wisconsin.

Beveridge, W.H. (1944) Full employment in a free society, London, Allen and Unwin.

Blinder, A. (1987) Hard heads soft hearts, Reading, Addison-Wesley.

Cook, B., Dodds. C. and Mitchell, W.F. (2003) 'Social entrepreneurship: False premises and dangerous forebodings', Australian Journal of Social Issues, 38(1), 5775.

Friedman, M. (1968) 'The role of monetary policy', American Economic Review, 58, $1-17$.

Giddens, A. (1998) The Third Way: The Renewal of Social Democracy, Cambridge, Cambridge University Press.

Jamrozik, A. (2001) Social policy in the post-welfare state, Sydney, Longman.

Jones, M. and MacLeod, G. (2002) 'Where's the Value in the New Regionalism?', Presented to the Royal Geographical Society-Institute of British Geographers’ Annual Conference, Queen’s University, Belfast, January 2-6.

Layard, R. (1998) 'Getting people back to work', CentrePiece, Autumn, 24-27.

Mitchell, W.F. (1998) 'The buffer stock employment model - Full employment without a NAIRU', Journal of Economic Issues, 32(2), 547-555. 
Mitchell, W.F. (2001a) 'The unemployed cannot find jobs that are not there!', in Mitchell, W.F. and E. Carlson (eds.), Unemployment: the tip of the iceberg, Sydney: CAER-UNSW Press, 85-116.

Mitchell, W.F. and Mosler, W.B. (2006) 'Understanding the economic fallacies of the intergenerational debate’, Australian Journal of Social Issues, 41(2), 159-170.

Mitchell, W.F. and Muysken, J. (2008) Full employment abandoned: shifting sands and policy failures, Aldershot, Edward Elgar.

OECD (1994) Jobs Study, Organisation for Economic Co-operation and Development, Paris.

OECD (2001) Innovations in labour market policies, the Australian way, Organisation for Economic Co-operation and Development, Paris.

Ormerod, P. (1994) The death of economics, London, Faber and Faber.

Peck, J. (2001) Workfare State, New York, Guilford.

Quirk, V. (2003) 'The problem of a full employment economy, in: Carlson, E.A. (ed.), The Full Employment Imperative, Proceedings of the $5^{\text {th }}$ path to full employment conference and the $10^{\text {th }}$ National Conference on Unemployment, 209-222.

Siegel, R.L. (1994) Employment and human rights: the international dimension, Philadelphia: University of Pennsylvania Press.

Solow, R.M. (1998) 'What is the labour-market flexibility? What is it good for?', Proceedings of the British Academy, 97, 189-211.

Thurow, L.C. (1983) Dangerous currents: The state of economics, Oxford, Oxford University Press.

Timmins, N. (1995) The five giants: A biography of the welfare state, London, Harper Collins.

Vickrey, W. (1993) 'Today’s Task for Economists', American Economic Review, 83(1), 1-10.

\footnotetext{
${ }^{1}$ The authors are Professor of Economics and Director of Centre of Full Employment and Equity at the University of Newcastle, Australia (Mitchell) and Professor of Economics and Director, CofFEEEurope, University of Maastricht, The Netherlands (Muysken).

${ }^{2}$ Arthur Altmeyer was one of the most influential persons shaping the course of social security in America. He was part of the President's Committee on Economic Security that drafted the original legislative proposal in 1934. He was a member of the three-person Social Security Board created to run the new program, and he was either Chairman of the Board or Commissioner for Social Security from 1937-1953.

${ }^{3}$ The authors acknowledge that the US is more difficult to classify in these terms. The rethoric applies more easily to the English speaking countries such as Australia, Canada and New Zealand and parts of Europe which followed in varying ways and to varying degrees of intensity Thatcherist approaches. While the Reagan era in the US waxed heavily about free markets and liberalisation, the reality was that discretionary fiscal policy was still employed as before. Only under the Clinton surpluses, which supported the Greenspan emphasis on inflation-first monetary policy stances, did the US accord more closely with the neo-liberal model outlined in the paper.

4 What are the costs of inflation? Blinder (1987: 45-50) 'More precisely, is the popular aversion to inflation based on fact and logic or on illusion and prejudice? ... Too many trips to the bank? Can that be what all the fuss is about? ... Can that be all there is to the costs of inflation? The inefficiencies
} 
caused by hyperinflation are, of course, monumental. But the costs of moderate inflation that I have just enumerated seem meager at best.' Blinder (1987: 51) also reacts to critics who lay all manner of societal ills on inflation at 6 per cent: 'Promiscuity? Sloth? Perfidy? When will inflation be blamed for floods, famine, pestilence, and acne? ... the myth that the inflationary demon, unless exorcised, will inevitably grow is exactly that - a myth. There is neither theoretical nor statistical support for the popular notion that inflation has a built-in tendency to accelerate. As rational individuals, we do not volunteer for a lobotomy to cure a head cold. Yet, as a collectivity, we routinely prescribe the economic equivalent of lobotomy (high unemployment) as a cure for the inflationary cold. Why?'

${ }^{5}$ This even holds in the Euro area as we argue in Chapter 8 of Mitchell and Muysken (2008). 